\title{
Spatiotemporal characteristics and driving mechanism of the coupling coordination degree of urbanization and ecological environment in Kazakhstan
}

\author{
HUANG Jinchuan ${ }^{1,2}$, NA Ying ${ }^{1,2}$, GUO Yu ${ }^{1,2,3}$ \\ 1. Institute of Geographic Sciences and Natural Resources Research, CAS, Beijing 100101, China; \\ 2. College of Resources and Environment, University of Chinese Academy of Sciences, Beijing 100049, China; \\ 3. School of Ecology Technology and Engineering, Shanghai Institute of Technology, Shanghai 201418, China
}

\begin{abstract}
When viewed against the backdrop of globalization and the Belt and Road Initiative $(B R I)$, Central Asia has ushered in new development opportunities. However, problems of ecological environment as a consequence of urbanization have begun to act as a constraint on the economic development of the region. the coupling coordination degree between the urbanization and ecological environment in Kazakhstan was analyzed by the coupling coordination degree model. The main controlling factors affecting its development were explored using a geographical detector. Several main conclusions can be drawn. (1) Kazakhstan's urbanization level, ecological environment level, and the coupling coordination degree between urbanization and ecological environment are all on the rise. (2) In terms of the comprehensive urbanization index, the western and eastern states have higher values than the southern and northern states. The spatial distribution pattern of the ecological environment index revealed high values in the eastern and western regions and low values in the central region. (3) The coupling coordination degree among the states of Kazakhstan is mostly at a low-moderate level. The spatial distribution shows that the coordination level of the east, middle, and west of the country is higher than that of south and north. (4) Indicators such as GDP per capita, social fixed asset investment per capita, employment in industry and services (\% of total employment), and the number of college students per 10,000 people are important urbanization factors that affect the coupling coordination degree of urbanization and ecological environment. Indicators of farmland areas per capita, availability of water resources per capita, ecological land per capita and forest coverage in the ecological environment subsystem are important ecological environmental factors that affect the degree of coordination between urbanization and ecological environment in Kazakhstan. The interaction of the main elements in the two subsystems has a strong synergy.
\end{abstract}

Keywords: Kazakhstan; comprehensive urbanization; ecological environment; synergistic effects; Belt and Road Initiative; geographical detector

Received: 2020-03-22 Accepted: 2020-08-31

Foundation: Strategic Priority Research Program of the CAS, Pan-Third Pole Environment Study for a Green Silk Road, No.XDA20040402

Author: Huang Jinchuan (1973-), PhD and Associate Professor, specialized in urban geography and planning. E-mail: huangjc@igsnrr.ac.cn 


\section{Introduction}

Central Asia is located at the junction between Europe and Asia and is a transportation hub for the Eurasian continent. The ancient Silk Road traverses Central Asia, and modern Central Asia is also the strategic core area of the Silk Road Economic Belt (Mao, 2013; Liu et al., 2018). Central Asia is the primary location through which China has opened-up to the West. China and Central Asia have mutual interests in terms of security, economy, and energy. In-depth cooperation with Central Asia is an important development direction for China in the future, and is also the only way to promote the prosperity of western China and Central Asia (Wuzhati et al., 2014).

Since the beginning of the new century, Central Asia has ushered in new development opportunities. Both economic development and urbanization levels are increasing in the region. According to the law of global urban expansion, the urbanization levels of the five Central Asian countries will continue to increase. However, Central Asia, which lies deep in the middle of the Eurasian continent, is the main body of the Eurasian inland arid zone. It is one of the most arid regions in the world and the carrying capacity of the environment is very limited (Cowan, 2007). As urbanization has advanced, the scale and intensity of resource utilization and environmental degradation has continued to expand and increase. The process of regional urbanization may be constrained by a restriction of resource availability and an environmental "threshold." The neglect of these regional resource and environmental issues will inevitably become an obstacle to urbanization development. The occurrence of the maritime crisis is an example of this.

For ecologically fragile areas, such as arid areas, the coordinated development of urbanization and the ecological environment is essential for regional sustainable development. Kazakhstan, which accounts for $68 \%$ of Central Asia's land area, has developed from a major agricultural economy to a major energy and mineral resource development country in recent years. The pace of social and economic development has accelerated. It has entered a rapid industrialization track before the other four countries, and the speed of urbanization has also accelerated. From an urbanization development model led by traditional industrialization, the urbanization rate of Kazakhstan has long ranked first among the five Central Asian countries, reaching more than $50 \%$. According to the general law of urbanization development in various countries around the world, when a country's urbanization level reaches $40 \%$ to $60 \%$, it is considered to be urbanized. Economic development in Kazakhstan has entered the golden period, and the country is also facing a period with the frequent occurrence of "urban diseases" (Ma, 2020). Therefore, Kazakhstan can be used as a model for the development of urbanization in the five Central Asian countries. It is of great significance to regard Kazakhstan as a key area for studying the coordinated development of urbanization and the ecological environment in Central Asia.

\section{Literature review}

The process of urbanization has caused increasingly serious negative effects worldwide, leading to a far-reaching impact on ecological environment (Fang et al., 2019b). Studies of the interaction and coupling of urbanization and the ecological environment are currently a research hot spot and represent the frontier of our current understanding of the hu- 
man-environment relationship and sustainability science (Reid et al., 2010; Kates et al., 2013; Fang et al., 2019a). Most previous studies of the impact of urbanization on ecological environment have focused on internal factors (Buyantuyev et al., 2010), the ecological environmental response in rapidly urbanizing areas (Wang et al., 2013), the constraints of ecological environment on urbanization (Bao and Fang, 2009), and the relationship between urbanization and ecological environmental systems (Qiao and Fang, 2005; Zhang et al., 2016). In terms of theoretical research on the coupling of urbanization and ecological environment, international studies have mainly focused on the pressure-state-response (PSR) model (Berger and Hodge., 1998), environmental Kuznets curve (Grossman and Krueger., 1995), ecological footprint theory (Rees and Wackernagel, 1996), decoupling theory (OECD, 2002), and telecoupling theory (Liu et al., 2007). Chinese researchers have also conducted theoretical research work and have proposed the theory of the "society-economy-nature" compound ecosystem (Ma and Wang, 1984), and the theory of the coupling circle of urbanization and ecological environment (Fang et al., 2019a). In recent years, studies have been undertaken on the interaction and coupling of urbanization and ecological environment, including the coupling mechanism and a regularity analysis (Huang and Fang, 2003), a coupled dynamic simulation (Cui et al., 2019), and theoretical and empirical research on the conceptual framework of a "coupling cube" (Liu et al., 2019). Research has shown that the interaction between urbanization and ecological environment has complex one-to-one, one-to-many, and many-to-many relationships (Fang, 2004). Researchers have studied this issue from different angles, focusing on the interactive coupling between urbanization and water resources and water environmental systems (Yang and Liu, 2014; Cao et al., 2019), and the interactive coupling between urbanization and land resource systems (Yang et al., 2011; Zheng et al., 2013), the interaction and coupling between urbanization and atmospheric environment (Kyrkilis et al., 2007), the interaction and coupling between urbanization and energy consumption and carbon emissions (Fan and Li, 2011; Guan et al., 2013; Wang and Cheng, 2020), and the interaction and coupling of urbanization, ecosystems, and biodiversity (Estoque and Murayama, 2013; Li et al., 2019). In general, the existing research has focused on one-to-one and one-to-many interactive coupling analyses between urbanization and ecological environment, with little research on the many-to-many elements, i.e., an overall interactive coupling analysis of the urbanization system and the ecological environmental system.

Although there has been little empirical research on urbanization and the impact on ecological environment in many countries, a large number of multi-scale studies, including the state (Liu et al., 2005; Zhang and Jiao, 2015), local administrative units (Fan et al., 2015), urban agglomerations and metropolitan areas (Liu et al., 2018; Zhao et al., 2020), as well as other typical areas such as watersheds (Du, 2014) and oases in arid areas (Tang et al., 2014), have been conducted in China. Most developed countries have gone through the stage of rapid urbanization and development, while most developing countries are still in the initial stage of urbanization development, and the ecological environmental problems have not been adequately addressed. Most countries will experience urbanization development, and will therefore require protection of the ecological environment. However, Central Asia faces particularly severe problems due to its fragile ecological environment. Studies of these problems have mostly focused on those caused by urbanization or human activities, espe- 
cially the damage to the water environmental system (Deng and Chen 2017; Yang et al., 2017), land use (Kuang et al., 2014) and ecosystems (Vakhlamova et al., 2014; Jiang et al., 2017). A few researchers have begun to pay attention to Central Asia, including one-to-one research on urbanization and ecological environment (Xiong and Yang, 2015).

In summary, researchers have studied the interaction and coupling of urbanization and ecological environment in China, but fewer such studies have been conducted elsewhere in the world. Much research has been conducted on the "one-to-one" and "two-element" interactive coupling between urbanization and ecological environment, with fewer studies on the coordination of "multi-element" coupling. As the first country in Central Asia to transform its economy, Kazakhstan is now experiencing rapid urbanization. How to manage the conflict between urbanization and the ecological environment has become an important issue regarding social development in this region. Therefore, this study applied data for both human and natural elements in Kazakhstan to research the processes of dynamic change in urbanization and ecological environment of Kazakhstan at province and national scales, and the coupling coordination degree between these two complex systems were assessed by constructing a coupling coordination degree model. A geographical detector was used to analyze the interaction between urbanization and various elements of the complex system in Kazakhstan, with the main control factors affecting the coordination degree being quantitatively identified. Finally, corresponding countermeasures and suggestions are proposed, which will provide a scientific reference for the coordination and sustainable development of urbanization and ecological environment in arid regions such as Kazakhstan and Central Asia, and ensure the prosperity and development of the "Belt and Road" region.

\section{Research area, data sources, and an evaluation index system}

\subsection{Study area and data sources}

Kazakhstan lies in the northern part of Central Asia, which borders on Turkmenistan, Uzbekistan, and Kyrgyzstan to the south, Russia to the north, China to the east, and the Caspian Sea to the west. It covers an area of $272.49 \mathrm{~km}^{2}$ and comprises $68 \%$ of the Central Asian region. Kazakhstan is located in the middle latitudes of the northern hemisphere (north temperate zone), covering 15 degrees of latitude from $40^{\circ} \mathrm{N}$ to $55^{\circ} \mathrm{N}$ and 35 degrees of longitude from $50^{\circ} \mathrm{E}$ to $85^{\circ} \mathrm{E}$. It has a population of approximately 72.5 million, with $55 \%$ of the population living in urban areas. It contains many ecological zones, but the principal biomes are, in the order of increasing aridity: steppe, semi-desert, and desert. About $60 \%$ of Kazakhstan's territory (179.9 million ha) is desert (Kirsten, 2004). It consists of various geomorphological types and has distinctive regional topographical features. Most of its territory consists of plains and lowlands, with the lowest point being in the western part of the Karagieh Basin at $132 \mathrm{~m}$ below sea level. The northeastern and southeastern parts consist of the Altai and Tianshan Mountains, of which the highest point is located in the central border of the Khan Tengri, with an altitude of $6995 \mathrm{~m}$. The central part consists of the Kazakh Hills, which have a general height of 300-500 m, with the highest point being $1565 \mathrm{~m}$. Kazakhstan has an abundance of mineral and fossil fuel resources, and ranks 11th in the world in terms of proven oil and gas reserves. Since 1993, the development of oil, gas, and minerals has attracted more than 40 billion USD in foreign investment, accounting for about $57 \%$ of the 
country's total industrial output (about 13\% of its GDP). In 2017, Kazakhstan had a permanent population of 18.038 million and a GDP of 159.47 billion USD, accounting for $25.30 \%$ and $60.11 \%$, respectively, of the totals among the five Central Asian countries.

Administratively, the territory of Kazakhstan is divided into 14 regions, consisting of districts and settlements. In addition, two cities, Almaty and Nur-Sultan, are classified as having republican significance. Considering its geographical location and socio-economic characteristics, the Kazakhstan region has traditionally been referred to as five macro areas: northern (Akmolinskaya, Kostanaiskaya, Pavlodarskaya, Severo-Kazakhstanskaya), central (Karagandinskaya), eastern (Vostochno-Kazakhstanskaya), western (Aktubinskaya, Atyrauskaya, Mangistauskaya, Zapadno-Kazakhstanskaya), and southern (Almatinskaya, YuzhnoKazakhstanskaya, Kyzylordinskaya, Zhambylskaya).

Socio-economic and environmental data for the Kazakhstan region at the oblast scale (from 2000 to 2017) and country scale (from 1992 to 2018) were used in this study, all of which were obtained from the official website of the Kazakhstan statistics bureau ${ }^{1}$ (The State Statistics Bureau of Kazakhstan, http://stat.gov.kz/) and the World Bank Open Data (https://data.worldbank.org.cn). World Development Indicators (WDI) is the main database for World Bank development data. This study used European Space Agency (ESA) 1992-2015 data (data source, http://maps.elie.ucl.ac.be/CCI/viewer/download.php) for global land cover (ESA Glob Cover) as the basis for the measurement of built-up and natural land.

\subsection{The evaluation index system}

To determine the coordination degree between urbanization and ecological environment in Central Asia, an indicator system for urbanization and ecological environment was constructed based on previous literature (Du et al., 2020; Ma, 2020). A comprehensive evaluation system suitable for urbanization and ecological environment in Central Asia was constructed based on the principles of science, maneuverability, a systematic structure, independence, generality, foresightedness, and data accessibility. The results are shown in Tables 1 and 2. Urbanization is a function of urban population growth (population urbanization), economic growth (economic urbanization), the expansion of urban space (spatial urbanization), and the improvement of people's living standards and quality (social urbanization). Population urbanization and spatial urbanization are physically apparent, while economic urbanization is the foundation and driving force of the process, and improvement in the quality of urban living standards is the ultimate goal of urbanization. The ecological environmental index used in the study covered the ecological environmental status, ecological environmental attributes, ecological environmental pressure, and ecological environmental responses.

\section{Research methods}

The commonly used weighting methods mainly include the expert investigation method (Delphi method), the analytic hierarchy process (AHP), the binomial coefficient method, the principal component analysis method, the entropy method, the deviation and mean square

${ }^{1}$ Due to the availability of data, we only obtained relevant data at the state scale for Kazakhstan from 2000 to 2017 , while the data obtained at the national scale are from 1992 to 2018. 
Table 1 Index system for urbanization.

\begin{tabular}{|c|c|c|c|c|c|}
\hline First-level index & Weight & Basic-level index & $\begin{array}{c}\text { Entropy } \\
\text { weight }\end{array}$ & $\begin{array}{l}\text { Coefficient of vari- } \\
\text { ation weight }\end{array}$ & $\begin{array}{l}\text { Comprehensive } \\
\text { weight }\end{array}$ \\
\hline \multirow{2}{*}{$\begin{array}{l}\text { Population } \\
\text { urbanization }\end{array}$} & \multirow[b]{2}{*}{0.108} & Urban population ( $\%$ of total) & 0.499 & 0.543 & 0.521 \\
\hline & & $\begin{array}{l}\text { Employment in industry and services } \\
\text { (\% of total employment) }\end{array}$ & 0.501 & 0.457 & 0.479 \\
\hline \multirow{4}{*}{$\begin{array}{l}\text { Spatial } \\
\text { urbanization }\end{array}$} & \multirow{4}{*}{0.504} & Urban population density (person $/ \mathrm{km}^{2}$ ) & 0.469 & 0.429 & 0.451 \\
\hline & & $\begin{array}{l}\text { Percentage of built-up areas in total } \\
\text { land area }(\%)\end{array}$ & 0.431 & 0.396 & 0.416 \\
\hline & & $\begin{array}{l}\text { Number of built-up areas per } 10,000 \\
\text { people }\left(\mathrm{km}^{2}\right)\end{array}$ & 0.040 & 0.086 & 0.059 \\
\hline & & $\begin{array}{l}\text { Density of road network per } 10,000 \\
\text { people }\left(\mathrm{km}^{2}\right)\end{array}$ & 0.061 & 0.090 & 0.074 \\
\hline \multirow{4}{*}{$\begin{array}{l}\text { Economic } \\
\text { urbanization }\end{array}$} & \multirow{4}{*}{0.247} & GDP per capita (USD) & 0.258 & 0.254 & 0.257 \\
\hline & & $\begin{array}{l}\text { Industry and services, value added (\% } \\
\text { of GDP) }\end{array}$ & 0.027 & 0.067 & 0.043 \\
\hline & & $\begin{array}{l}\text { Gross industrial output value per capita } \\
\text { (USD) }\end{array}$ & 0.393 & 0.352 & 0.374 \\
\hline & & Per capita social fixed assets investment & 0.322 & 0.327 & 0.326 \\
\hline \multirow{4}{*}{$\begin{array}{l}\text { Social } \\
\text { urbanization }\end{array}$} & \multirow{4}{*}{0.140} & $\begin{array}{l}\text { Per capita income and consumption } \\
\text { expense }\end{array}$ & 0.293 & 0.284 & 0.290 \\
\hline & & $\begin{array}{l}\text { Number of public buses per } 10,000 \\
\text { people }\end{array}$ & 0.281 & 0.295 & 0.289 \\
\hline & & $\begin{array}{l}\text { Number of college students per } 10,000 \\
\text { people }\end{array}$ & 0.132 & 0.182 & 0.156 \\
\hline & & $\begin{array}{l}\text { Number of professional doctors per } \\
10,000 \text { people }\end{array}$ & 0.293 & 0.238 & 0.265 \\
\hline
\end{tabular}

Table 2 Index system for ecological environment.

\begin{tabular}{|c|c|c|c|c|c|}
\hline First-level index & Weight & Basic-level index & $\begin{array}{c}\text { Entropy } \\
\text { weight }\end{array}$ & $\begin{array}{c}\text { Coefficient of } \\
\text { variation weight }\end{array}$ & $\begin{array}{c}\text { Comprehensive } \\
\text { weight }\end{array}$ \\
\hline \multirow{3}{*}{$\begin{array}{l}\text { Ecological } \\
\text { environmental status }\end{array}$} & \multirow{3}{*}{0.357} & $\begin{array}{l}\text { Renewable internal freshwater resources } \\
\text { per capita }\left(\mathrm{m}^{2}\right)\end{array}$ & 0.374 & 0.292 & 0.332 \\
\hline & & Arable land area (ha per person) & 0.304 & 0.344 & 0.325 \\
\hline & & Cereal production per capita (metric $\mathrm{kg}$ ) & 0.323 & 0.363 & 0.344 \\
\hline \multirow{2}{*}{$\begin{array}{l}\text { Ecological } \\
\text { environmental } \\
\text { attributes }\end{array}$} & \multirow{2}{*}{0.170} & Forest area ( $\%$ of land area) & 0.637 & 0.624 & 0.631 \\
\hline & & Ecological land per capita $\left(\mathrm{m}^{2}\right)$ & 0.363 & 0.376 & 0.369 \\
\hline \multirow{3}{*}{$\begin{array}{l}\text { Ecological } \\
\text { environmental } \\
\text { pressure }\end{array}$} & \multirow{3}{*}{0.363} & $\begin{array}{l}\text { Emissions of solid pollutants (kg per } \\
\text { capita) }\end{array}$ & 0.346 & 0.319 & 0.332 \\
\hline & & $\begin{array}{l}\text { Emissions of liquid and gaseous pollutant } \\
\text { substances (kg per capita) }\end{array}$ & 0.319 & 0.322 & 0.321 \\
\hline & & $\begin{array}{l}\text { Emissions of free air pollutants, from } \\
\text { non-stationary sources (kg per capita) }\end{array}$ & 0.335 & 0.359 & 0.347 \\
\hline \multirow{3}{*}{$\begin{array}{l}\text { Ecological } \\
\text { environmental } \\
\text { response }\end{array}$} & \multirow{3}{*}{0.110} & $\begin{array}{l}\text { Running expenses for ecological envi- } \\
\text { ronmental protection (thousand tenge) }\end{array}$ & 0.438 & 0.261 & 0.346 \\
\hline & & Removal rate of pollutants (\%) & 0.233 & 0.234 & 0.238 \\
\hline & & Recycling rate of pollutants (\%) & 0.329 & 0.505 & 0.416 \\
\hline
\end{tabular}

error method, the multi-objective programming method, and the projection tracking model. The entropy method has been widely used to define index weights in geography and environmental science and reflects the validity of information provided by the index. It reflects the original information of the index and improves the objectivity of the evaluation.

As the original data were not comparable due to the large differences of dimensional and units, standardization of the data range was used to make data being dimensionless. The original index was therefore divided into two: the positive index and negative index. The 
larger the positive index, the more favorable it was for the development of the system (conversely, the larger the negative index, the more unfavorable it was). To eliminate the deviation of a single objective weighting method and to avoid the arbitrariness and error of the subjective weighting method, the entropy method and variation coefficient method were combined in this study to ensure the accuracy and reliability of the results.

$$
\left\{\begin{array}{l}
S_{i j}=\frac{x_{i j}-\min \left\{x_{i j}\right\}}{\max \left\{x_{i j}\right\}-\min \left\{x_{i j}\right\}}(\text { the index is positive }) \\
S_{i j}=\frac{\max \left\{x_{i j}\right\}-x_{i j}}{\max \left\{x_{i j}\right\}-\min \left\{x_{i j}\right\}}(\text { the index is negative })
\end{array}\right.
$$

where $x_{i j}$ is the value of the $j$ th indicator in the $i$ th oblast; and $\max \left\{x_{i j}\right\}$ and $\min \left\{x_{i j}\right\}$ represent the maximum and minimum values of the $j$ th index in the $i$ th country, respectively.

The calculated weights of urbanization and ecological environmental system evaluation indexes are shown in Tables 1 and 2. The comprehensive weight of the indicators was calculated as follows:

$$
W_{i}=\frac{\left(w_{1 i *} w_{2 i}\right)^{1 / 2}}{\sum_{i=1}^{n}\left(w_{1 i^{*}} w_{2 i}\right)^{1 / 2}}
$$

where $w_{1 i}$ and $w_{2 i}$ are the entropy weight and variation coefficient weight; and $W_{i}$ is the comprehensive weight.

\subsection{Comprehensive evaluation model}

The subsystems of population urbanization, economic urbanization, social urbanization, and spatial urbanization; and ecological environmental status, ecological environmental attributes, ecological environmental pressure, and ecological environmental response were calculated using the linear weighting method.

The evaluation of the index values of urbanization and ecological environmental system was calculated as follows:

$$
\begin{gathered}
u(x)=\sum_{i=1}^{n} w_{i}^{*} x_{i}, e(y)=\sum_{j=1}^{m} w_{j}^{*} y_{j} \\
U(x)=\sum_{i=1}^{n} W_{i}^{*} f(x), E(y)=\sum_{j=1}^{m} W_{j}^{*} g(y)
\end{gathered}
$$

where $u(x)$ and $e(y)$ are the comprehensive evaluation values of urbanization and ecological environmental system, respectively; $x_{i}$ and $y_{j}$ are the standardized values of the urbanization and ecological environmental evaluation indicators; $w_{i}$ and $w_{j}$ represent the comprehensive weights for the assessment of urbanization and ecological environmental indicators respectively; and $W_{i}$ and $W_{j}$ represent the weight of urbanization and ecological environment respectively. For Central Asia, the development of urbanization seems to be as important as ecological environmental quality. The values of $w_{i}$ and $w_{j}$ are therefore equal.

\subsection{An urbanization and ecological environmental coordination model}

Coupling refers to the phenomenon in which two (or more) systems are affected by the var- 
various interactions between them and the outside world. The coupling degree model (5), which depicts the relationship between a pair of parameters, is widely used to study the interaction between urbanization and ecological environment.

$$
T=\left\{\frac{f(U) g(E)}{(f(U)+g(E)) 1 / 2)^{2}}\right\}^{1 / 2}
$$

We further constructed the coupling coordination degree model for urbanization and ecological environment to identify the degree of coordination between the coupling of urbanization and ecological environment, namely:

$$
\begin{gathered}
C=\alpha f(U)+\beta g(E) \\
D=\sqrt{C T}
\end{gathered}
$$

where $C$ is the coupling degree between urbanization and ecological environment $(C \in(0$, $1)) ; f(U)$ is the urbanization subsystem; and $g(E)$ is the ecological environmental subsystem; $D$ is the coupling coordination degree between urbanization and ecological environment; $T$ represents the comprehensive reconciliation index of urbanization and ecological environment; $\alpha$ and $\beta$ represent the contribution of urbanization and ecological environment, respectively. For Central Asia, we assumed that the development of urbanization is as impor-

\begin{tabular}{|c|c|c|c|c|c|}
\hline $\begin{array}{l}\text { Primary divi } \\
\text { development }\end{array}$ & $\begin{array}{l}\text { ision of } \\
\text { al stages }\end{array}$ & $\begin{array}{l}\text { Secondary division of } \\
\text { developmental stages }\end{array}$ & Tertiary di & vision of developmental stages & Code \\
\hline & & & $\mathrm{E}(\mathrm{y})-\mathrm{U}(\mathrm{x})>0.1$ & $\begin{array}{l}\text { Uncoordinated; urbanization is } \\
\text { blocked }\end{array}$ & I1 \\
\hline & $0<\mathrm{D} \leqslant 0.2$ & Severe imbalance & $|\mathrm{E}(\mathrm{y})-\mathrm{U}(\mathrm{x})| \leqslant 0.1$ & Balanced development & $\mathrm{I} 2$ \\
\hline Unceordingtod & & & $\mathrm{E}(\mathrm{y})-\mathrm{U}(\mathrm{x})<-0.1$ & $\begin{array}{l}\text { Uncoordinated; ecological envi- } \\
\text { ronment is blocked }\end{array}$ & $\mathrm{I} 3$ \\
\hline & & & $\mathrm{E}(\mathrm{y})-\mathrm{U}(\mathrm{x})>0.1$ & $\begin{array}{l}\text { Low-level coordination; urbaniza- } \\
\text { tion is blocked }\end{array}$ & II1 \\
\hline & $0.2<\mathrm{D} \leqslant 0.4$ & Moderate imbalance & $|\mathrm{E}(\mathrm{y})-\mathrm{U}(\mathrm{x})| \leqslant 0.1$ & Balanced development & II2 \\
\hline & & & $\mathrm{E}(\mathrm{y})-\mathrm{U}(\mathrm{x})<-0.1$ & $\begin{array}{l}\text { Low-level coordination; ecological } \\
\text { environment is blocked }\end{array}$ & II3 \\
\hline & & & $\mathrm{E}(\mathrm{y})-\mathrm{U}(\mathrm{x})>0.1$ & $\begin{array}{l}\text { Basic coordination; urbanization is } \\
\text { blocked }\end{array}$ & III1 \\
\hline & $0.4<\mathrm{D} \leqslant 0.6$ & Low coordination & $|\mathrm{E}(\mathrm{y})-\mathrm{U}(\mathrm{x})| \leqslant 0.1$ & Balanced development & III 2 \\
\hline Trancition noriod & & & $\mathrm{E}(\mathrm{y})-\mathrm{U}(\mathrm{x})<-0.1$ & $\begin{array}{l}\text { Basic coordination; ecological } \\
\text { environment is blocked }\end{array}$ & III3 \\
\hline 11ansition pentod & & & $\mathrm{E}(\mathrm{y})-\mathrm{U}(\mathrm{x})>0.1$ & $\begin{array}{l}\text { High-level coordination; urbaniza- } \\
\text { tion is blocked }\end{array}$ & IV1 \\
\hline & $0.6<\mathrm{D} \leqslant 0.8$ & Moderate coordination & $|\mathrm{E}(\mathrm{y})-\mathrm{U}(\mathrm{x})| \leqslant 0.1$ & Balanced development & IV2 \\
\hline & & & $\mathrm{E}(\mathrm{y})-\mathrm{U}(\mathrm{x})<-0.1$ & $\begin{array}{l}\text { High-level coordination; ecological } \\
\text { environment is blocked }\end{array}$ & IV3 \\
\hline & & & $\mathrm{E}(\mathrm{y})-\mathrm{U}(\mathrm{x})>0.1$ & $\begin{array}{l}\text { Uncoordinated; urbanization is } \\
\text { blocked }\end{array}$ & V1 \\
\hline $\begin{array}{l}\text { Highly coordi- } \\
\text { nated period }\end{array}$ & $0.8<\mathrm{D} \leqslant 1$ & Advanced coordination & $|\mathrm{E}(\mathrm{y})-\mathrm{U}(\mathrm{x})| \leqslant 0.1$ & Balanced development & $\mathrm{V} 2$ \\
\hline & & & $\mathrm{E}(\mathrm{y})-\mathrm{U}(\mathrm{x})<-0.1$ & $\begin{array}{l}\text { Uncoordinated; ecological envi- } \\
\text { ronment is blocked }\end{array}$ & V3 \\
\hline
\end{tabular}
tant as the quality of ecological environment, and therefore the values $\alpha$ and $\beta$ are equal.

Table 3 Classification of the synergistic development of urbanization and ecological environment. 
The coupling degree between urbanization and ecological environment can be divided into three main stages of development, each of which can be further divided into four sub-categories (Li et al., 2012). In Table 3, E(y) represents ecological environment, U(x) represents urbanization, and $\mathrm{D}$ is the coupling coordination degree.

\subsection{Geographical detector}

Geographical detectors were originally applied to assess the environmental risks to health (Wang et al., 2010). They can be used as a statistical method for detecting spatial differentiation and to explain the driving forces behind it (Wang and $\mathrm{Xu}, 2017$ ). Geographical detectors have less constraints than other models in terms of hypothesis formulation (Hu et al., 2011) and can analyze both numerical and qualitative data. They can also analyze the effects of two factors interacting with dependent variables. They have therefore been widely used to analyze the evolution of geographical elements and the differentiation of geographical space. The core idea of a factor detector is that geographical elements always exist in specific spatial locations, and the environmental factors affecting their development are spatially different. If a certain environmental factor has a significant spatial consistency with regard to the change of a geographical element, the environmental factor would be decisive for the occurrence and development of that geographical element (Wang et al., 2010).

\section{Results}

\subsection{Evolution of the coupling coordination degree between urbanization and ecological environmental systems at the national scale in Kazakhstan}

In this study, the original data at the national scale for Kazakhstan were standardized, and the trends of the coupling degree and coupling coordination degree between urbanization and ecological environment were calculated according to the coupling degree and coupling coordination degree formulas, respectively (Figure 1). From 1992 to 2018, the coupling degree presented an inverted "U"-shaped curve of "slow growth-stable growth-fast decline," and the coupling coordination degree maintained a continuous rising trend. A very close interaction between urbanization and ecological environment was identified in Kazakhstan. According to the changes in the coupling coordination degree, the development could be divided into three stages. (1) There was a relatively slow urbanization in the stage from 1992 to 2005. Due to a plenty of energy resources and through urban expansion, there was eventually rapid growth in population agglomeration, which increased the urbanization level. However, resource exploitation and industrial development during this stage generated enormous pressure on the ecological environment. (2) From 2005 to 2013, there was a period of concern for the ecological environment. After experiencing extensive economic growth, Kazakhstan introduced a number of environmental policies that focused on the promotion of high-quality urban development. This resulted in a slow decline in the coupling degree and a continuous increase in the coupling coordination degree. (3). From 2013 to 2018 , the ecological environment had a limiting effect on the rate of urbanization, leading to a decrease in urbanization and a decrease in the coupling coordination degree between urbanization and ecological environment. 


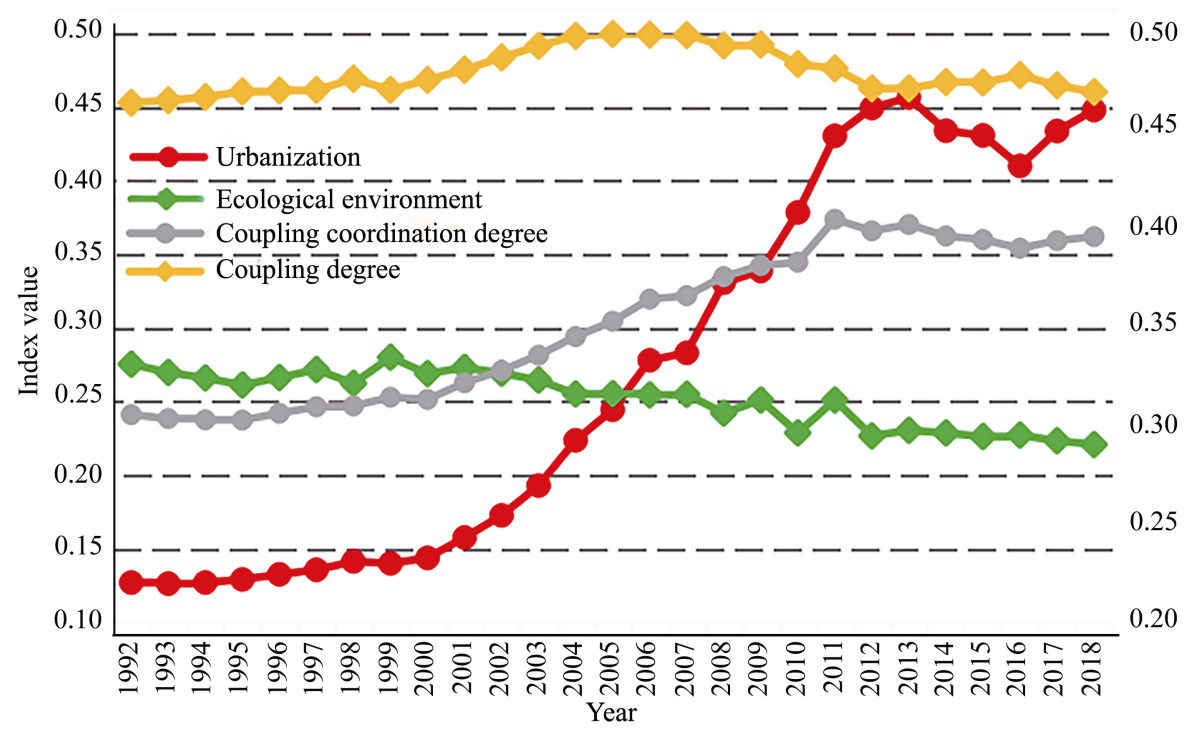

Figure 1 Urbanization and ecological environmental systems indexes and trends for the coupling coordination degree at the national scale in Kazakhstan

\subsection{Spatiotemporal evolution of the urbanization and ecological environmental systems and their interactions within the oblasts of Kazakhstan}

5.2.1 The spatiotemporal evolution of the comprehensive urbanization index within the oblasts of Kazakhstan

A statistical chart (Figure 2) for the years 2000-2017 was constructed to analyze the interaction between urbanization and ecological environment within the oblasts of Kazakhstan. The comprehensive urbanization index of various administrative regions in Kazakhstan increased over time. When the average annual level of urbanization in each administrative unit was compared, Almaty city (0.48-0.72) comprised the first echelon within the country. Nur-Sultan city $^{2}$ (0.37-0.54), Atyrauskaya (0.22-0.51), and Mangistauskaya (0.30-0.40) comprised the second echelon, which indicated that these units had an absolute advantage in terms of their urbanization level. Karagandinskaya (0.23-0.38), Pavlodarskaya (0.20-0.35), Zapadno-Kazakhstanskaya (0.17-0.35), and Aktubinskaya (0.17-0.33) comprised the third echelon. Yuzhno-Kazakhstanskaya (0.10-0.27), Severo-Kazakhstanskaya (0.08-0.22), Akmolinskaya (0.11-0.24), Zhambylskaya (0.12-0.22), and Almatinskaya (0.07-0.21) comprised the fourth echelon.

As shown in Figure 3, during the study period, the comprehensive urbanization index of all regions of Kazakhstan displayed an upward trend. In terms of spatial differentiation, the areas with higher levels of comprehensive urbanization were mainly distributed in provinces such as Atyrauskaya and Zapadno-Kazakhstanskaya in the west, which have an abundance of mineral resources (oil and gas reserves). Atyrauskaya is the province with the largest oil production and produces most of the crude oil in Kazakhstan. In 2017 it produced and condensate 42.39 million tons of crude oil (about $49.2 \%$ of the country's total output), and ex-

\footnotetext{
${ }^{2}$ Nur-Sultan was renamed in 2019, having originally being named Astana. For consistency, this paper uses the new name of Nur-Sultan.
} 
tracted 20.92 billion $\mathrm{m}^{3}$ of natural gas (about $40 \%$ of the national output). Its level of urbanization is relatively high and its industrial base of oil and gas exploration has driven regional economic development. The areas with low levels of urbanization are mainly distributed in parts of the south and north, such as Yuzhno-Kazakhstanskaya and Zhambylskaya in the south and Severo-Kazakhstanskaya and Kostanaiskaya in the north. These areas are mainly grassland and mountainous areas. The southern climatic conditions are mild and suitable for the development of the fruit and vegetable industry. The north is relatively cold and is an important grain-producing area. A quarter of Kazakhstan's grain comes from
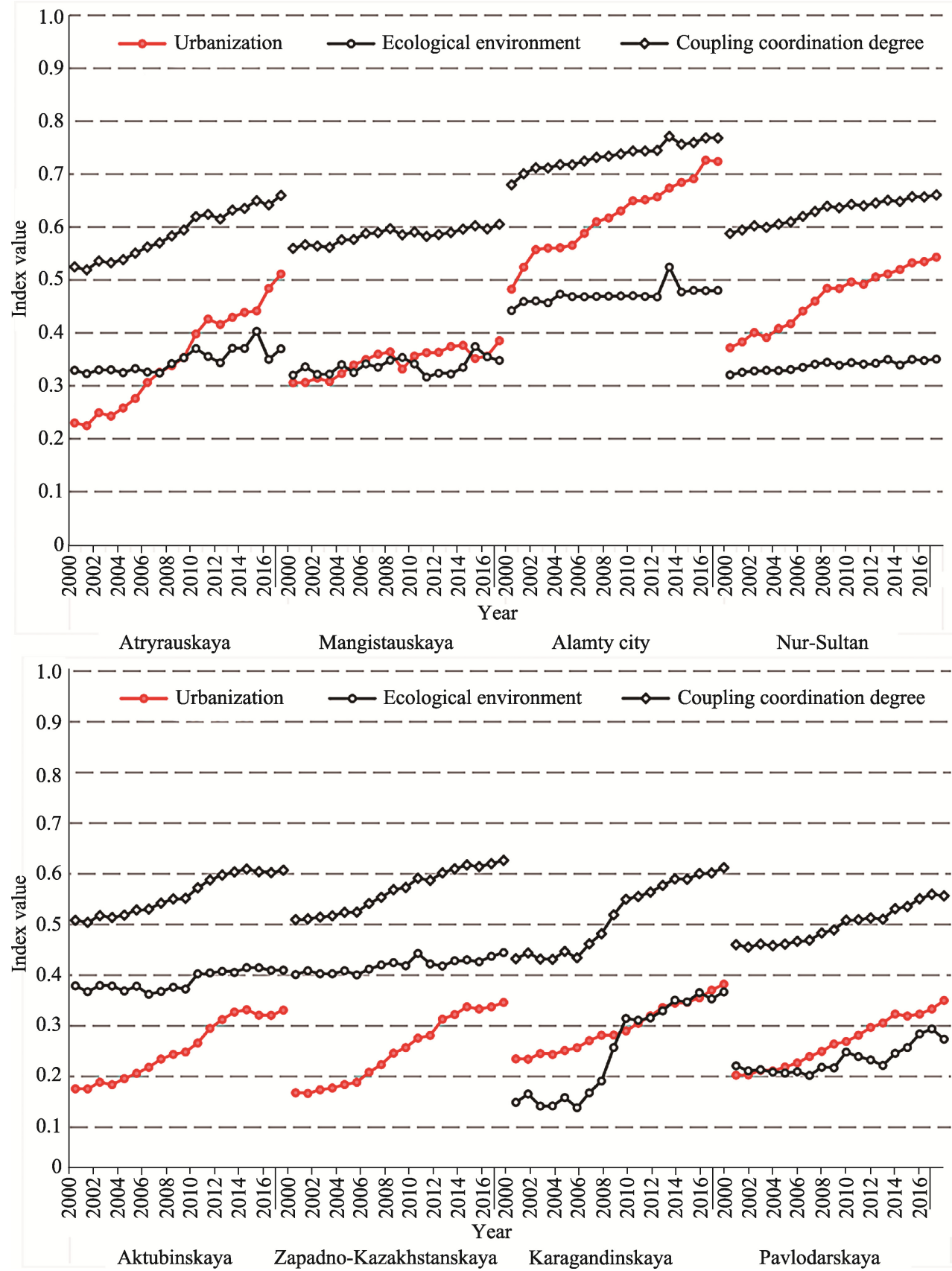


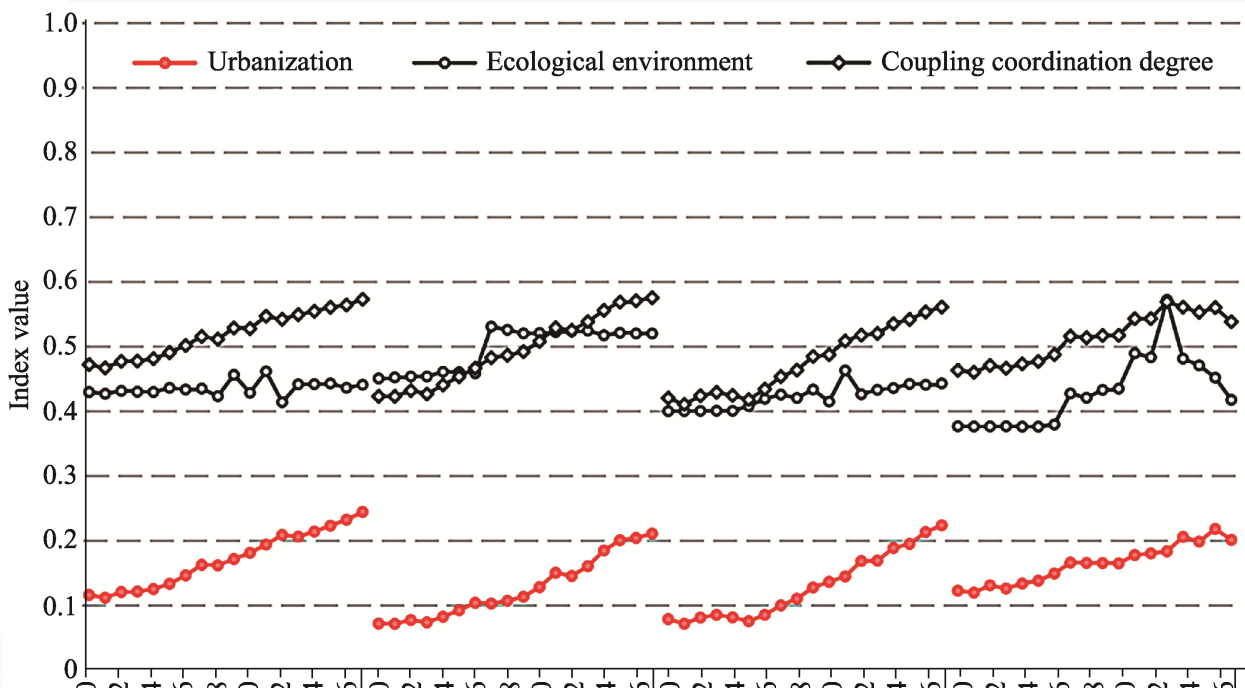

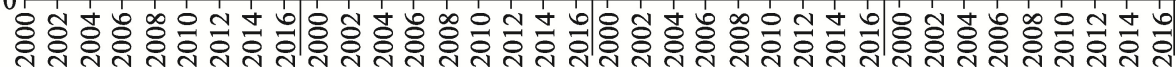
M

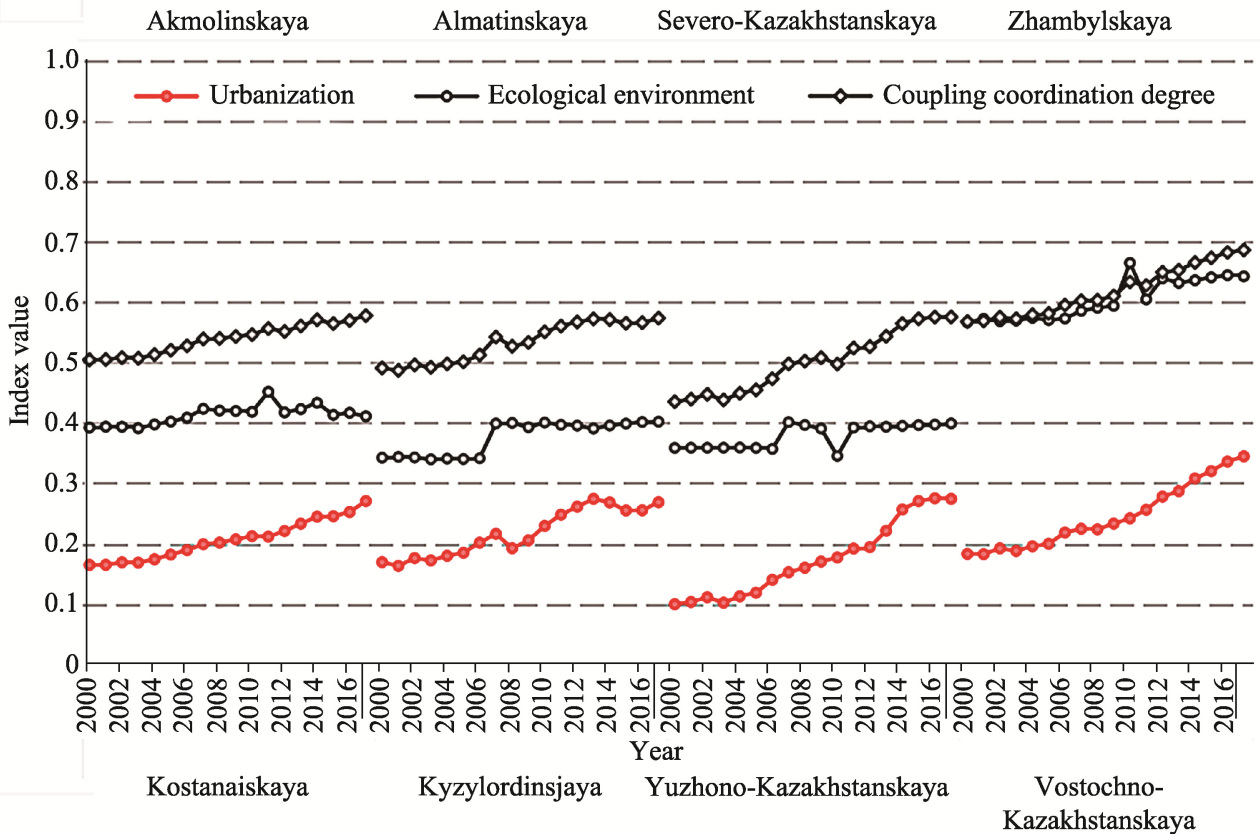

Figure 2 Urbanization and ecological environmental systems index values and trends for the coupling coordination degree within the oblasts of Kazakhstan

Kostanaiskaya. In 2017 and 2018, the grain output was 5.2 and 5 million tons, respectively. Because Kostanaiskaya is mainly engaged in agricultural development, its level of economic development is generally lower than the average national level. With relatively scarce mineral resources, infrastructure, and human resources, the overall level of urbanization is low. In the central and northeastern parts of the country, including Karagandinskaya, Pavlodarskaya, and Zapadno-Kazakhstanskaya, there is an intermediate level of urbanization. The climate of this region is of continental climatic type, which is cold and dry. Agricultural development is limited in this region, but due to its abundant mineral resources and the indus- 

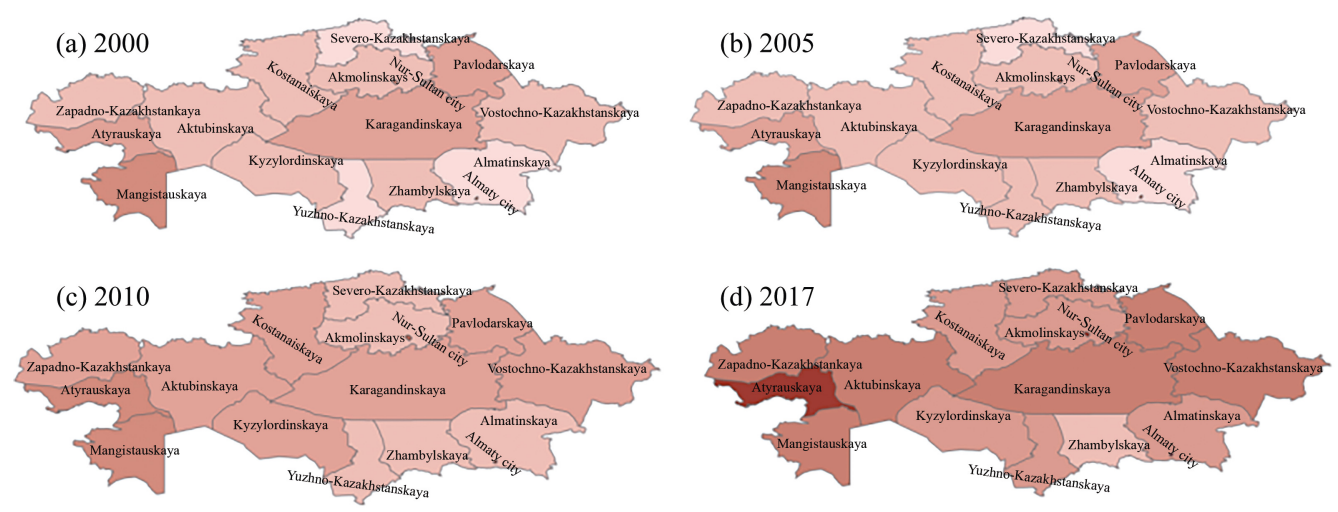

Comprehensive urbanization level

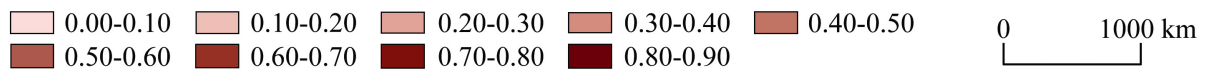

Figure 3 Spatiotemporal evolution of the comprehensive urbanization index within the oblasts of Kazakhstan from 2000 to 2017

trial facilities left over from the Soviet era, there are very favorable conditions for industrial development. Karagandinskaya is rich in non-ferrous metals and is the transit point of the Central Asia's oil pipeline and the Eurasian railway, while Pavlodarskaya is an important industrial base (Xing et al., 2015). The states around Almaty, Kazakhstan's largest and most industrialized city, and the capital city of Nur-Sultan have low levels of urbanization. Almaty and Nur-Sultan have little effect on promoting the urbanization of surrounding regions.

5.2.2 The spatiotemporal evolution of the comprehensive ecological environment index within the oblasts of Kazakhstan

Over time, the comprehensive ecological environment index of all regions of Kazakhstan displayed a fluctuating upward trend, indicating that Kazakhstan's overall ecological environment level has improved, but the overall increase has been small (Figure 2). In terms of its spatial distribution, the comprehensive index of ecological environment values was high in the east and west, and low in the central part of the country, where it is lowlying, with low ecological environmental quality (Figure 4). Overall, the comprehensive index of ecological environment values for Vostochno-Kazakhstanskaya in the east and Almatinskaya in the southeast were much higher than those of the other regions, because the eastern and southeastern parts of Kazakhstan contain mountains and valleys and have a good ecological foundation. Except for the Karagandinskaya and Pavlodarskaya regions, the comprehensive ecological environment index was consistent with the ecological background. The ecological conditions of the Karagandinskaya and Pavlodarskaya regions are considered to be moderately good, but the comprehensive ecological environment index values were the lowest among all regions of the country. This was mainly because they are industrial and mining areas, where development has occurred from industrial production such as metallurgy, coal, petroleum processing, and machinery manufacturing. Industrial development has caused environmental pollution. However, in recent years, Karagandinskaya's comprehensive ecological environment index has increased significantly, rising rapidly from 0.148 in 2000 to 0.314 in 2009, and finally reaching 0.367 in 2017 . 


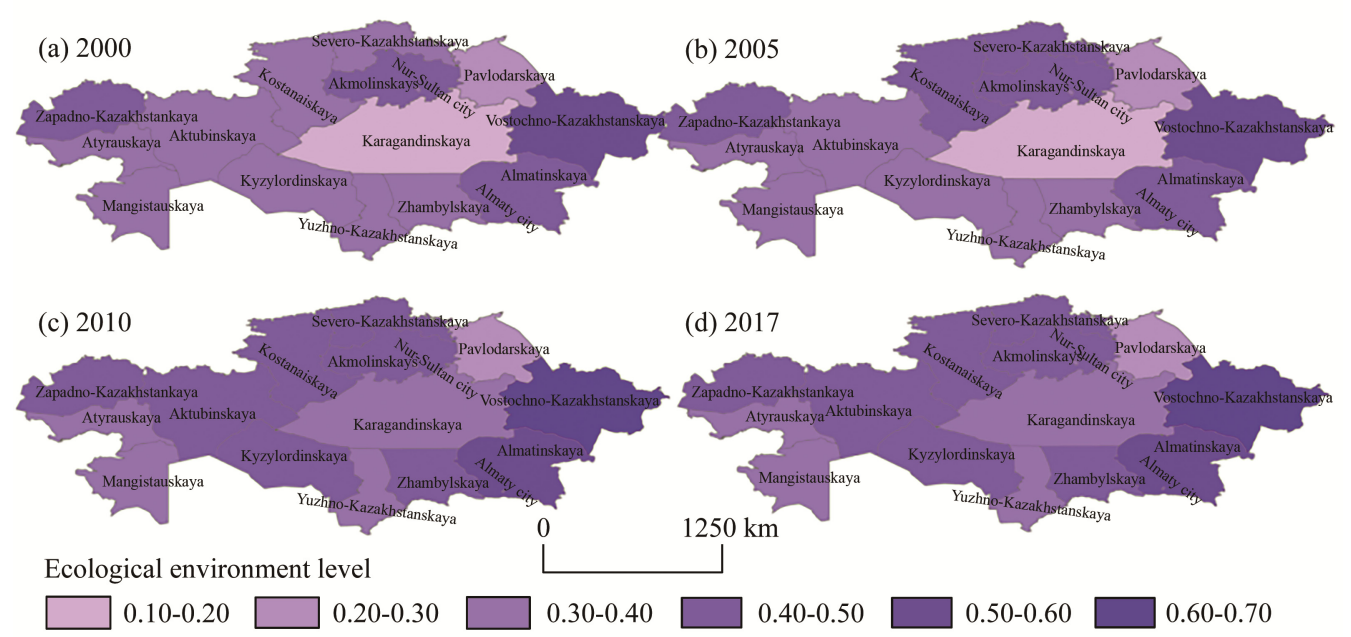

Figure 4 Spatiotemporal evolution of the comprehensive ecological environment index within the oblasts of Kazakhstan from 2000 to 2017

5.2.3 Spatiotemporal evolution of the interaction between the urbanization system and the ecological environmental system within the oblasts of Kazakhstan

The coupling coordination degree between the urbanization and ecological environment can be used to reflect not only the correlation between systems but also the size of the system index (Wang et al., 2019). For those oblasts where the relationship between urbanization and ecological environment was not in harmony, the exploitation of resources and urban development was more restricted. The coupling coordination degree between urbanization and ecological environment within the oblasts of Kazakhstan from 2000 to 2017 was calculated to characterize the correlation and coordination of urbanization and ecological environment (Table 4), and to summarize the stage of development in each region.

In terms of the spatiotemporal differentiation of the coupling coordination degree between urbanization and ecological environment in Kazakhstan, the states mainly had a low-moderate level of coordination and were at the stage of transformation and development. In terms of spatial distribution, the coordination level of the east, middle, and west of the country was higher than that of the south and north (Figure 5). This spatial distribution pattern indicated that the coordination degree between the coupling of the urbanization and ecological environmental systems had the characteristics of an area based on industrial development rather than an area based on agricultural development. Topographically, the coupling coordination degree in the plains area was higher than that in the mountains. Over time, most of Kazakhstan's eastern, central, and western states changed from a low to medium level of coordinated development (Table 5), while most of the northern and southern states were still at a low level of coordinated development, but they changed over time from being dominated by the ecological environment to experiencing urbanization and development. With the introduction of developmental policies in Kazakhstan, much attention has been given to sustainable development, and most regional coordination policies have been gradually upgraded. Almaty, the largest metropolis not only in Kazakhstan but also in the whole of Central Asia, has always been at a stage of moderate coordination. Almaty, the city with the 


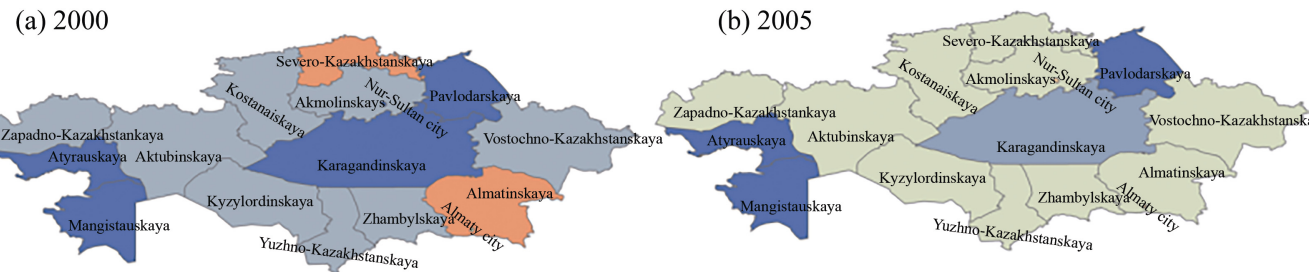

(c) 2010

(d) 2017

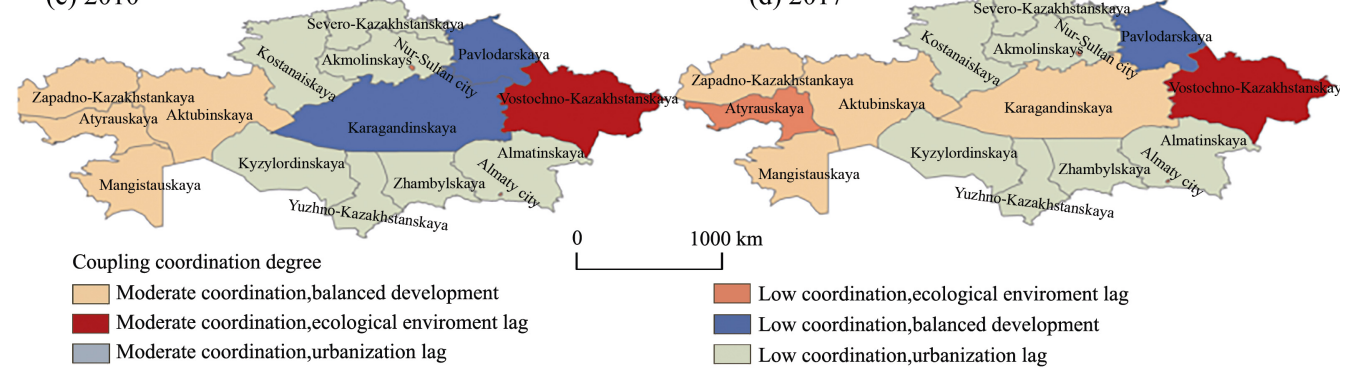

Figure 5 Spatiotemporal evolution of the coupling coordination degree within the oblasts of Kazakhstan from 2000 to 2017

Table 4 Summary of the coupling coordination degree of urbanization and ecological environment within the oblasts of Kazakhstan from 2000 to 2017

\begin{tabular}{|c|c|}
\hline Region & 200020012002200320042005200620072008200920102011201220132014201520162017 \\
\hline $\begin{array}{l}\text { Akmolin- } \\
\text { skaya }\end{array}$ & 0.4710 .4660 .4760 .4760 .4800 .4900 .5000 .5140 .5100 .5280 .5270 .5460 .5410 .5480 .5530 .5600 .5630 .572 \\
\hline $\begin{array}{l}\text { Aktubin- } \\
\text { skaya }\end{array}$ & 0.5080 .5040 .5170 .5130 .5180 .5280 .5300 .5420 .5500 .5510 .5720 .5870 .5970 .6030 .6090 .6040 .6020 .607 \\
\hline $\begin{array}{l}\text { Almatin- } \\
\text { skaya }\end{array}$ & 0.4000 .4220 .4310 .4250 .4390 .4520 .4650 .4820 .4850 .4910 .5070 .5280 .5240 .5370 .5550 .5680 .5700 .574 \\
\hline \multicolumn{2}{|r|}{ Atyrauskaya 0.5240 .5190 .5350 .5320 .5380 .5500 .5620 .5700 .5830 .5940 .6190 .6240 .6150 .6320 .6350 .6490 .6410 .659} \\
\hline Zapadno- & \\
\hline $\begin{array}{l}\text { Kazakh- } \\
\text { stanskaya }\end{array}$ & 0.5090 .5100 .5140 .5160 .5230 .5240 .5410 .5530 .5680 .5720 .5910 .5870 .6010 .6090 .6170 .6140 .6190 .626 \\
\hline $\begin{array}{l}\text { Zhambyl- } \\
\text { skaya }\end{array}$ & 0.4620 .4590 .4700 .4650 .4720 .4760 .4860 .5150 .5130 .5160 .5160 .5420 .5420 .5680 .5600 .5520 .5590 .537 \\
\hline $\begin{array}{l}\text { Karagandi- } \\
\text { nskaya }\end{array}$ & 0.4320 .4430 .4310 .4310 .4460 .4340 .4610 .4810 .5180 .5490 .5550 .5630 .5770 .5890 .5890 .6000 .6010 .612 \\
\hline $\begin{array}{l}\text { Kostanais- } \\
\text { kaya }\end{array}$ & 0.5040 .5050 .5080 .5070 .5130 .5200 .5280 .5390 .5400 .5430 .5460 .5560 .5510 .5600 .5710 .5640 .5690 .577 \\
\hline $\begin{array}{l}\text { Kyzylordin- } \\
\text { skaya }\end{array}$ & 0.4910 .4870 .4960 .4920 .4980 .5010 .5120 .5420 .5270 .5330 .5510 .5600 .5670 .5720 .5710 .5650 .5660 .573 \\
\hline $\begin{array}{l}\text { Mangista- } \\
\text { uskaya } \\
\text { Yuzhno- }\end{array}$ & 0.5590 .5660 .5640 .5610 .5760 .5760 .5880 .5890 .5970 .5850 .5900 .5820 .5860 .5890 .5960 .6020 .5960 .605 \\
\hline $\begin{array}{l}\text { Kazakh- } \\
\text { stanskaya }\end{array}$ & 0.4350 .4390 .4470 .4380 .4490 .4550 .4730 .4980 .5020 .5080 .4970 .5240 .5260 .5430 .5640 .5720 .5750 .575 \\
\hline $\begin{array}{l}\text { Pavlodar- } \\
\text { skaya }\end{array}$ & 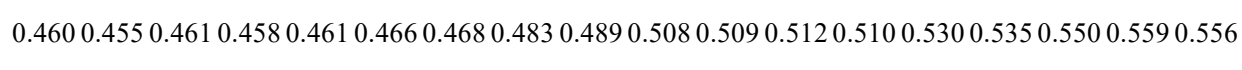 \\
\hline $\begin{array}{l}\text { Seve- } \\
\text { ro-Kazakhst } \\
\text { anskaya }\end{array}$ & 0.4000 .4090 .4230 .4280 .4230 .4170 .4330 .4520 .4620 .4830 .4860 .5070 .5160 .5190 .5340 .5410 .5520 .560 \\
\hline $\begin{array}{l}\text { Vostoch- } \\
\text { no-Kazakh- } \\
\text { stanskaya }\end{array}$ & 0.5680 .5690 .5750 .5720 .5790 .5810 .5950 .6020 .6030 .6100 .6330 .6270 .6490 .6530 .6650 .6730 .6820 .686 \\
\hline $\begin{array}{l}\text { Nur-Sultan } \\
\text { city }\end{array}$ & 0.5870 .5940 .6020 .5990 .6050 .6090 .6200 .6290 .6390 .6360 .6430 .6400 .6450 .6500 .6480 .6570 .6560 .660 \\
\hline Almaty city & 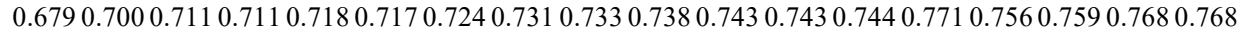 \\
\hline
\end{tabular}


Table 5 Classification table of the coupling coordination degree of urbanization and ecological environment within the oblasts of Kazakhstan from 2000 to 2017 (for details of the codes used here refer to Table 3)

\begin{tabular}{|c|c|c|c|c|c|c|c|c|c|c|c|c|c|c|c|c|c|c|}
\hline Region & 2000 & 20 & 200 & 200 & 2004 & 200 & 2006 & 2007 & 2008 & 2009 & 2010 & 2011 & 2012 & 201 & 2014 & 201 & 201 & 2017 \\
\hline Akmolinskaya & III1 & III1 & III1 & III1 & III1 & III1 & III1 & III1 & III1 & III1 & III1 & III1 & III1 & III1 & III1 & III1 & III1 & III1 \\
\hline Aktubinskaya & III1 & III1 & III1 & III1 & III1 & III1 & III1 & III1 & III1 & III1 & III1 & III1 & III2 & IV2 & IV2 & IV2 & IV2 & IV2 \\
\hline Almatinskaya & II1 & III1 & III1 & III1 & III1 & III1 & III1 & III1 & III1 & III 1 & III1 & III1 & III1 & III1 & III1 & III1 & III1 & III1 \\
\hline Atyrauskaya & III2 & III2 & III2 & III2 & III2 & III2 & III2 & III2 & III2 & III2 & IV2 & IV2 & IV2 & IV2 & IV2 & IV2 & IV3 & IV3 \\
\hline $\begin{array}{l}\text { Zapadno-Kaza- } \\
\text { khstanskaya }\end{array}$ & III1 & III1 & III1 & III1 & III1 & III1 & III1 & III1 & III1 & III1 & III1 & III1 & IV1 & IV1 & IV2 & IV2 & IV2 & IV2 \\
\hline Zhambylskaya & III1 & III1 & III1 & III1 & III1 & III1 & III1 & III1 & III1 & III1 & III1 & III 1 & III1 & III1 & III1 & III1 & III1 & III1 \\
\hline Karagandinskaya & III2 & III 2 & III3 & III3 & III2 & III3 & III3 & III2 & III2 & III2 & III2 & III 2 & III 2 & III2 & III2 & III 2 & IV2 & IV2 \\
\hline Kostanaiskaya & III1 & III1 & III1 & III1 & III1 & III1 & III1 & III1 & III1 & III1 & III1 & III1 & III1 & III1 & III1 & III1 & III1 & III1 \\
\hline Kyzylordinskaya & III1 & III1 & III1 & III1 & III1 & III1 & III1 & III1 & III1 & III1 & III1 & III1 & III1 & III1 & III1 & III 1 & III1 & III1 \\
\hline Mangistauskaya & III2 & III 2 & III2 & III2 & III2 & III2 & III2 & III2 & III2 & III2 & III2 & III 2 & III2 & III2 & III2 & IV2 & III2 & IV2 \\
\hline $\begin{array}{l}\text { Yuzhno-Kaza- } \\
\text { khstanskaya }\end{array}$ & III1 & III1 & III1 & III1 & III1 & III1 & III1 & III1 & III1 & III1 & III1 & III1 & III1 & III1 & III1 & III1 & III1 & III1 \\
\hline Pavlodarskaya & III2 & III 2 & III2 & III2 & III2 & III2 & III2 & III2 & III2 & III2 & III 2 & III 2 & III2 & III2 & III2 & III 2 & III2 & III 2 \\
\hline $\begin{array}{l}\text { Severo- } \\
\text { Kazakhstanskaya }\end{array}$ & II1 & III1 & III1 & III1 & III1 & III1 & III1 & III1 & III1 & III1 & III1 & III 1 & III1 & III1 & III1 & III1 & III1 & III1 \\
\hline $\begin{array}{l}\text { Vostochno- } \\
\text { Kazakhstanskaya }\end{array}$ & III1 & III1 & III1 & III1 & III1 & III1 & III1 & IV1 & IV1 & IV1 & IV1 & IV1 & IV1 & IV1 & IV1 & IV1 & IV1 & IV1 \\
\hline Nurs-Sultan city & III2 & III 2 & IV2 & III2 & IV2 & IV2 & IV3 & IV3 & IV3 & IV3 & IV3 & IV3 & IV3 & IV3 & IV3 & IV3 & IV3 & IV3 \\
\hline Almaty city & IV2 & IV2 & IV2 & IV3 & IV2 & IV2 & IV3 & IV3 & IV3 & IV3 & IV3 & IV3 & IV3 & IV3 & IV3 & IV3 & IV3 & IV3 \\
\hline
\end{tabular}

highest coupling coordination degree, is not only the largest city in Kazakhstan, but is also the most competitive city in Central Asia. It has a high concentration of human resources, a strong financial foundation, a complete education system and a developed infrastructure. The coupling of rapid economic growth and the Almaty municipal government's heavy investment in environmental protection in recent years resulted in the coupling coordination degree being much higher than the state average and it continues to remain stable.

\subsection{The dominant factors influencing the degree of coordination between Kazakh- stan's urbanization and ecological environmental systems}

Geographical spatial factors affect the spatial differentiation of the interaction between urbanization and ecological environment. Based on the calculated coupling coordination degree between urbanization and ecological environment in Kazakhstan, we conducted an equal-isolation and decentralized treatment for 25 indicators of the urbanization and ecological environmental systems. We then input these results into geographical detector software to calculate the $q$ values affecting the coupling coordination degree between urbanization and ecological environment. Other than the number of professional doctors per 10,000 people and the recycling and re-use rate of waste materials, all other indicators passed the test at a significance level of 0.05 . Specifically, in the urbanization subsystem, the indicators of GDP per capita, social fixed asset investment per capita, employment in industry and services (\% of total employment), and the number of college students per 10,000 people were found to be important factors in the coupling coordination degree in Kazakhstan, with $q$ values that were much higher than the average. The GDP per capita is an important indicator 
of regional economic development, and indicates the level of economic growth and urbanization. Urbanization leads to higher economic productivity due to its positive externalities and economies of scale. A higher GDP can attract more innovative talent, and thus promote the establishment of innovative industries without causing high levels of pollution. Research, funding, and educational programs that favor green technology companies are currently flourishing, which will boost the market for green technologies, and thus improve environmental performance. An increasing number of college students will lead to industrial innovation and attract talents to the region, which will promote the high-quality development of regional urbanization. Urbanization promotes the development of service industries because it bridges the gap between intermediary organizations and clients. An outstanding business location, with high-quality talents in an environment in which productivity flourishes will increase the total investment in regional fixed assets, which is in turn a positive factor. These were considered to be important driving forces behind the sustainable and coordinated development of the region.

In the ecological environment subsystem, indicators such as farmland areas per capita, availability of water resources per capita, ecological land per capita, and forest coverage were found to be important factors in the coupling coordination degree in Kazakhstan. In oases of arid areas, the influence of water resources on urbanization was the most decisive factor. An uncontrolled escalation of urbanization tends to result in a deterioration of water systems (Zhang et al., 2012; Liu et al., 2014), and water resources are particularly important for Kazakhstan. With the rapid development of the petroleum and mining industries in recent years, the availability of water resources has declined. For example, the total amount of renewable water resources in Akmolinskaya decreased from 133,000 million $\mathrm{m}^{3}$ in 2001 to 54 million $\mathrm{m}^{3}$ in 2016. In the northern part of Kazakhstan, there are large areas of savanna, which play a vital role in regional and global carbon storage (Propastin et al., 2008; Eisfelder et al., 2012). Therefore, the protection of land and forest resources plays an important indirect driving role in the interaction between urbanization and ecological environment.

This research on Kazakhstan revealed that the interaction between urbanization and ecological environmental factors had a strong influence on the overall degree of coordination, and they also have a strong synergy. Only the pollutant recovery rate index (i.e., the recycling rate of pollutants) and the value added of industry and services (i.e., \% of GDP) were independent of each other, and the interaction between urbanization and ecological environment for these parameters was not significant. Table 6 lists the interactions where the two-factor interaction $q$ value was greater than 0.7 . It can be seen that the q value of the interaction factor increased significantly after these interactions. Employment in industry and services ( $\%$ of total employment) interacted most frequently with the other factors. Employment in industry and services (\% of total employment) interacted with the per capita air pollutant index to have the greatest comprehensive impact on the coupling coordination degree of urbanization and ecological environment. To some extent, employment in industry and services (\% of employment) reflected the vitality of regional productivity, and some heavy industries and service industries inevitably produced air pollution. Factors such as the number of college students per 10,000 people, GDP per capita, and social fixed asset investment per capita, interacted with other factors multiple times. This shows that economic and social development, and industrial transformation and upgrading have played an impor- 


\section{tant role in promoting the coordinated development of Kazakhstan's urbanization and eco- logical environmental systems.}

Table 6 Dominant interaction factors affecting the harmony between urbanization and ecological environment in Kazakhstan

\begin{tabular}{|c|c|c|c|c|c|}
\hline Dominant interaction factor & $q$ & $\begin{array}{l}\text { Dominant interaction } \\
\text { factor }\end{array}$ & $q$ & Dominant interaction factor & $q$ \\
\hline $\begin{array}{l}\text { Employment in industry and } \\
\text { services (\% of total employ- } \\
\text { ment) } \cap \text { GDP per capita }\end{array}$ & 0.709 & $\begin{array}{l}\text { Cereal production per } \\
\text { capita } \cap \text { Urban popula- } \\
\text { tion }(\% \text { of total })\end{array}$ & 0.717 & $\begin{array}{l}\text { Recycling rate of pollutants } \cap \\
\text { Employment in industry and ser- } \\
\text { vices ( } \% \text { of total employment) }\end{array}$ & 0.713 \\
\hline $\begin{array}{l}\text { Employment in industry and } \\
\text { services (\% of total employ- } \\
\text { ment) } \cap \text { Gross industrial out- } \\
\text { put value per capita }\end{array}$ & 0.703 & $\begin{array}{l}\text { Cereal production per } \\
\text { capita } \cap \text { Employment in } \\
\text { industry and services ( } \% \\
\text { of total employment) }\end{array}$ & 0.752 & $\begin{array}{l}\text { Emissions of liquid and gasiform } \\
\text { pollutant substances } \cap \text { Employ- } \\
\text { ment in industry and services ( } \% \\
\text { of total employment) }\end{array}$ & 0.787 \\
\hline $\begin{array}{l}\text { Employment in industry and } \\
\text { services (\% of total employ- } \\
\text { ment) } \cap \text { Social fixed asset } \\
\text { investment per capita }\end{array}$ & 0.705 & $\begin{array}{l}\text { Ecological land per } \\
\text { capita } \cap \text { GDP per capita }\end{array}$ & 0.743 & $\begin{array}{l}\text { Emissions of solid pollutants } \cap \\
\text { Employment in industry and ser- } \\
\text { vices ( } \% \text { of total employment) }\end{array}$ & 0.762 \\
\hline $\begin{array}{l}\text { Employment in industry and } \\
\text { services ( } \% \text { of total employ- } \\
\text { ment) } \cap \text { Number of public } \\
\text { buses per } 10,000 \text { people }\end{array}$ & 0.704 & $\begin{array}{l}\text { Ecological land per } \\
\text { capita } \cap \text { Employment in } \\
\text { industry and services ( } \% \\
\text { of total employment) }\end{array}$ & 0.731 & $\begin{array}{l}\text { Emissions of free air pollutants, } \\
\text { divergent from stationary sources } \\
\cap \text { Employment in industry and } \\
\text { services (\% of total employment) }\end{array}$ & 0.803 \\
\hline $\begin{array}{l}\text { Employment in industry and } \\
\text { services ( } \% \text { of total employ- } \\
\text { ment) } \cap \text { Number of built-up } \\
\text { areas per } 10,000 \text { people }\end{array}$ & 0.758 & $\begin{array}{l}\text { Forest areas ( } \% \text { of land } \\
\text { area) } \cap \text { Employment in } \\
\text { industry and services ( } \% \\
\text { of total employment) }\end{array}$ & 0.788 & $\begin{array}{l}\text { Emissions of liquid and gasiform } \\
\text { pollutant substances } \cap \text { Gross } \\
\text { industrial output value per capita }\end{array}$ & 0.751 \\
\hline $\begin{array}{l}\text { Per capita income and con- } \\
\text { sumption expenses } \cap \text { Em- } \\
\text { ployment in industry and ser- } \\
\text { vices ( } \% \text { of total employment) }\end{array}$ & 0.721 & $\begin{array}{l}\text { Forest area }(\% \text { of land } \\
\text { area }) \cap \text { GDP per capita }\end{array}$ & 0.758 & $\begin{array}{l}\text { Emissions of liquid and gasiform } \\
\text { pollutant substances } \cap \text { Social } \\
\text { fixed asset investment per capita }\end{array}$ & 0.753 \\
\hline $\begin{array}{l}\text { Number of public buses per } \\
10,000 \text { people } \cap \text { Employment } \\
\text { in industry and services ( } \% \text { of } \\
\text { total employment) }\end{array}$ & 0.750 & $\begin{array}{l}\text { Forest area }(\% \text { of land } \\
\text { area }) \cap \text { Urban popula- } \\
\text { tion }(\% \text { of total })\end{array}$ & 0.748 & $\begin{array}{l}\text { Emissions of free air pollutants } \\
\text { from non-stationary sources } \cap \\
\text { Gross industrial output value per } \\
\text { capita }\end{array}$ & 0.717 \\
\hline $\begin{array}{l}\text { Number of college students per } \\
10,000 \text { people } \cap \text { GDP per } \\
\text { capita }\end{array}$ & 0.731 & $\begin{array}{l}\text { Forest area ( } \% \text { of land } \\
\text { area) } \cap \text { Number of col- } \\
\text { lege students per } 10,000 \\
\text { people }\end{array}$ & 0.729 & $\begin{array}{l}\text { Emissions of free air pollutants } \\
\text { from non-stationary sources } \cap \\
\text { social fixed asset investment per } \\
\text { capita }\end{array}$ & 0.711 \\
\hline $\begin{array}{l}\text { Number of college students per } \\
10,000 \text { people } \cap \text { social fixed } \\
\text { asset investment per capita }\end{array}$ & 0.711 & $\begin{array}{l}\text { Forest area ( } \% \text { of land } \\
\text { area) } \cap \text { Arable land area } \\
\text { (hectares per person) }\end{array}$ & 0.716 & $\begin{array}{l}\text { Emissions of free air pollutants } \\
\text { from non-stationary sources } \cap \\
\text { Urban population ( } \% \text { of total) }\end{array}$ & 0.717 \\
\hline $\begin{array}{l}\text { Number of college students per } \\
10,000 \text { people } \cap \text { Number of } \\
\text { public buses per } 10,000 \text { people }\end{array}$ & 0.720 & $\begin{array}{l}\text { Running expenses for } \\
\text { environmental protection } \\
\cap \text { Urban population }\end{array}$ & 0.756 & $\begin{array}{l}\text { Emissions of free air pollutants } \\
\text { from non-stationary sources } \cap \\
\text { Urban population ( } \% \text { of total) }\end{array}$ & 0.704 \\
\hline $\begin{array}{l}\text { Number of college students per } \\
10,000 \text { people } \cap \text { Employment } \\
\text { in industry and services }\end{array}$ & 0.783 & $\begin{array}{l}\text { Running expenses on } \\
\text { environmental protection } \\
\cap \text { Employment in indus- } \\
\text { try and services }\end{array}$ & 0.739 & & \\
\hline $\begin{array}{l}\text { Number of college students per } \\
10,000 \text { people } \cap \text { Per capita } \\
\text { income and consumption ex- } \\
\text { penses }\end{array}$ & 0.712 & $\begin{array}{l}\text { Running expenses on } \\
\text { environmental protection } \\
\cap \text { Number of college } \\
\text { students per } 10,000 \\
\text { people }\end{array}$ & 0.751 & & \\
\hline $\begin{array}{l}\text { Number of college students per } \\
10,000 \text { people } \cap \text { Number of } \\
\text { public buses per } 10,000 \text { people }\end{array}$ & 0.784 & $\begin{array}{l}\text { Purification rate of pol- } \\
\text { lutants } \cap \text { Employment in } \\
\text { industry and services }\end{array}$ & 0.726 & & \\
\hline
\end{tabular}




\section{Conclusions and discussion}

\subsection{Conclusions}

In this study, a comprehensive evaluation index system for urbanization and ecological environment in Central Asia was constructed. Taking Kazakhstan as a case study, the spatiotemporal changes of the coupling degree and coupling coordination degree between the comprehensive index of urbanization and ecological environment at the national and state scales were analyzed. A geographical detector model was used to identify the main factors controlling the interaction between urbanization and ecological environment in Kazakhstan. The conclusions can be drawn as follows:

(1) The coupling degree between urbanization and ecological environment in Kazakhstan at the national scale displayed an inverted "U" shaped curve, indicating a pattern of "slow growth - stable growth - fast decline," while the coupling coordination degree displayed a continuous upward trend.

(2) In recent years, the coupling of urbanization and ecological environment of Kazakhstan has shown an upward trend. For states with a high level of industrialization, the level of urbanization was significantly higher than that of states with a high level of agricultural production. From a spatial perspective, the comprehensive urbanization index values for the western and eastern states were higher than those of the southern and northern states. In terms of the ecological environment, the comprehensive ecological environment index values for each state fluctuated and increased over the study period, but the increases were not large. The comprehensive ecological environment index presented a spatial distribution pattern of being high in the east and west and low in the central region. Except in Karaganda and Pavlodar, the comprehensive ecological environment index was mainly determined by the ecological background.

(3) Overall, the interaction between urbanization and ecological environmental system in the states of Kazakhstan had a relatively low level of coordination, but it displayed a positive development trend. The spatial distribution showed that the coordination level of the east, middle, and west of the country was higher than that of the south and north. The states with good industrialization development were in a moderately well-coordinated state, while in the states where agriculture was the main activity urbanization and ecological environment were poorly coordinated and there was a lack of economic development. The coordination degree in Almaty was the largest in the country.

(4) The investigation and identification of the main factors that affected the coordination degree between urbanization and ecological environment were determined based on a geographic detector model. The indicators of GDP per capita, social fixed asset investment per capita, employment in industry and services (\% of total employment), and the number of college students per 10,000 people were important urbanization factors that affected the coupling coordination degree of urbanization and ecological environment in Kazakhstan. The indicators of farmland areas per capita, availability of water resources per capita, ecological land per capita, and forest coverage were important environmental factors that affected the coordination degree between the coupling of urbanization and ecological environment in Kazakhstan. The interaction of each element in the two subsystems had a greater impact on the coupling coordination degree than any single element, and also had a strong synergy. 


\subsection{Discussion}

The ecological environment in Central Asia is fragile, with several prominent ecological problems. The industrial structure is dominated by agriculture and basic energy-based industries, and urbanization is severely restricted by ecological environmental conditions. Kazakhstan has the largest area and total economic output among the five Central Asian countries, as well as the highest level of urbanization and industrialization. The coordinated development of urbanization and protection of ecological environment has had a demonstrable effect on the sustainable development of Central Asia and arid regions elsewhere in the world. This study found that in the past ten years, Kazakhstan has shown a healthy and coordinated developmental trend between urbanization and protection of ecological environment. Some successful developments have occurred, but some problems still exist. Therefore, the following suggestions are proposed for the future development of Kazakhstan.

(1) Kazakhstan is still facing the problem of a lack of urbanization. It is necessary to accelerate the urbanization of the population, space, society, and economy, and narrow the gap between the various subsystems. To achieve a breakthrough in population urbanization, the transformation of the agricultural population from agriculture-based states to urban populations should be actively promoted to improve the population urbanization rate. The rate of infrastructure construction should be increased to improve the population carrying capacity of cities. Ecologically efficient industries should be promoted to replace traditional low-ecological efficient industries and production methods. An accelerated program of industrial upgrading would transform economic development patterns.

(2) Kazakhstan's industry is dominated by traditional oil and gas exploitation, and the ecological environment has been seriously damaged. Therefore, it is necessary to strengthen the environmental protection of resources, improve the efficiency of resource utilization, and gradually increase the carrying capacity of the local ecological environment. Increased investment in environmental protection is necessary, including the establishment of sewage treatment plants and sewage recycling facilities to relieve the pressure on water resources. It is also necessary to expand the area of vegetation cover, including forest areas, and to develop and use land rationally, whilst also remediating damaged land resources.

(3) The opportunity offered by the "Belt and Road" construction project should be seized to further accelerate the transformation and upgrading of the country's industrial structure. The industrial chain could be extended in terms of the traditional petrochemical industry by progressing from crude oil extraction to deep processing. The development potential of renewable energy should be exploited to develop clean energy. The introduction of professional talent is needed together with an improvement in the level of education. High-tech industries should be cultivated and developed, and tertiary industry should be developed in an appropriate manner.

\section{References}

Bao C, Fang C L, 2009. Scenario warning and analysis of water resources constraint intensity on urbanization in arid area. Journal of Natural Resources, 23(4): 239-244. (in Chinese)

Berger A R, Hodge R A, 1998. Natural change in the environment: A challenge to the pressure-state-response concept. Social Indicators Research, 44(2): 255-265. 
Buyantuyev A, Wu J, Gries C, 2010. Multiscale analysis of the urbanization pattern of the Phoenix Metropolitan landscape of USA: Time, space and thematic resolution. Landscape and Urban Planning, 94(3/4): 206-217.

Cao Q W, Bao C, Gu C L et al., 2019. China's urbanization SD modelling and simulation based on water resource constraints. Geographical Research, 38(1): 167-180. (in Chinese)

Cowan P J, 2007. Geographic usage of the terms Middle Asia and Central Asia. Journal of Arid Environments, 69(2): 359-363.

Cui X G, Fang C L, Liu H M et al., 2019. Dynamic simulation of urbanization and eco-environment coupling: A review on theory, methods and applications. Journal of Geographical Sciences, 74(6): 1079-1096. (in Chinese)

Deng H, Chen Y, 2017. Influences of recent climate change and human activities on water storage variations in Central Asia. Journal of Hydrology, 544: 46-57.

Du X, 2014. The coupling modeling and simulation measure between water resource and environment and socio-economic system: Based on Dongting Lake basin. Economic Geography, 34(8): 151-155. (in Chinese)

Du X, Meng Y R, Fang C L et al., 2020. Spatio-temporal characteristics of coupling coordination development between urbanization and eco-environment in Shandong Peninsula urban agglomeration. Acta Ecologica Sinica, 40(16): 5546-5559. (in Chinese)

Eisfelder C, Kuenzer C, Dech S, 2012. Derivation of biomass information for semi-arid areas using remote-sensing data. International Journal of Remote Sensing, 33(9): 2937-2984.

Estoque R, Murayama Y, 2013. Landscape pattern and ecosystem service value changes: Implications for environmental sustainability planning for the rapidly urbanizing summer capital of the Philippines. Landscape and Urban Planning, 116: 60-72.

Fan J, Li P X, 2011. Analysis on the future energy consumption and preliminary discussion on carbon emission of China from the perspective urbanization. Advances in Earth Science, 26(1): 57-65. (in Chinese)

Fan J, Xu Y, Wang C et al., 2015. The effects of human activities on the ecological environment of Tibet over the past half century. Chinese Science Bulletin, 60(32): 3057-3066. (in Chinese)

Fang C L, 2004. Ecological Economic Corridor in Western China. Beijing: The Commercial Press, 78-86.

Fang C L, Cui X G, Liang L W, 2019a. Theoretical analysis of urbanization and eco-environment coupling coil and coupler control. Acta Geographica Sinica, 74(12): 2529-2546. (in Chinese)

Fang C L, Gao Q, Zhang X L, 2019b. Spatiotemporal characteristics of the expansion of an urban agglomeration and its effect on the eco-environment: Case study on the northern slope of the Tianshan Mountains. Science China Earth Sciences, 62: 1461-1472. (in Chinese)

Grossman G M, Krueger A B, 1995. Economic growth and the environment. Quarterly Journal of Economics, 110(2): 353-377.

Guan H L, Chen J C, Cao W, 2013. Empirical study on the relationship between carbon emission and urbanization. China Population, Resources and Environment, 23(4): 111-116. (in Chinese)

Hu Y, Wang J F, Li X H et al., 2011. Geographical detector-based risk assessment of the under-five mortality in the 2008 Wenchuan earthquake, China. PLoS ONE, 6(6): e21427.

Huang J C, Fang C L, 2003. Analysis of coupling mechanism and rules between urbanization and eco-environment. Geographical Research, 22(2): 211-220. (in Chinese)

Jiang L L, Guli·J, Bao A M et al., 2017. Vegetation dynamics and responses to climate change and human activities in Central Asia. Science of the Total Environment, 599/600: 967-980.

Kates R W, Clark W C, Corell R et al., 2001. Environment and development. Sustainability science. Science, 292(5517): 641-642.

Kuang W, Ma Y G, Li H et al., 2014. Analysis of land degradation intensity and trend in Central Asia from 1999 to 2012. Remote Sensing for Land and Resources, 26(4): 163-169. (in Chinese)

Kyrkilis G, Chaloulakou A, Kassomenos P A et al., 2007. Development of an aggregate air quality index for an urban Mediterranean agglomeration: Relation to potential health effects. Environment International, 33(5): $670-676$.

Li J Z, Dai Y H, Zhao W et al., 2019. Study on spatial-temporal characteristics of interaction coupling between 
regional urbanization system and ecosystem and early-warning of coordinated development: A case of Hunan province. Resources and Environment in the Yangtze Basin, 28(7): 1590-1601. (in Chinese)

Li Y, Li Y, Zhou Y et al., 2012. Investigation of a coupling model of coordination between urbanization and the environment. Journal of Environmental Management, 98: 127-133.

Liu H M, Fang C L, Huang J C et al., 2018. The spatial-temporal characteristics and influencing factors of air pollution in Beijing-Tianjin-Hebei urban agglomeration. Acta Geographica Sinica, 73(1): 177-191. (in Chinese)

Liu H M, Fang C L, Li Y H et al., 2019. The coupled human and natural cube: A conceptual framework for analyzing urbanization and eco-environment interactions. Acta Geographica Sinica, 74(8): 1489-1507. (in Chinese)

Liu H M, Shi P J, Yang X M et al., 2014. Self-organization evolution simulation and empirical study of human-water system. Journal of Natural Resources, 29(4): 709-718. (in Chinese)

Liu J G, Dietz T, Carpenter S R et al., 2007. Complexity of coupled human and natural systems. Science, 317(5844): 1513-1516.

Liu Y B, Li R D, Song X F et al., 2005. Analysis on the coupling degree of urbanization and ecological environment in China. Journal of Natural Resources, 20(1): 105-112. (in Chinese)

Ma S J, Wang R S, 1984. The social-economic-natural complex ecosystem. Acta Ecologica Sinica, 4(1): 3-11. (in Chinese)

Ma Y, 2020. Examining the coupling degree and interactive stress between urbanization and eco-environment in Yangtze River Economic Belt. Resources and Environment in the Yangtze Basin, 29(2): 275-286. (in Chinese)

Mao H Y, 2013. Prospects of energy cooperation of China with Russia and Central Asia countries. Progress in Geography, 32(10): 1433-1443. (in Chinese)

OECD, 2002. Indicators to Measure Decoupling of Environmental Pressure from Economic Growth. Paris: OECD.

Propastin P A, Kappas M, Muratova N R, 2008. A remote sensing based monitoring system for discrimination between climate and human-induced vegetation change in Central Asia. Management of Environmental Quality: An International Journal, 19(5): 579-596.

Qiao B, Fang C, 2005. The dynamic coupling model of the harmonious development between urbanization and eco-environment and its application in arid area. Acta Ecologica Sinica, 25(11): 3003-3009. (in Chinese)

Rees W, Wackernagel M, 1996. Urban ecological footprints: Why cities cannot be sustainable - And why they are a key to sustainability. Environmental Impact Assessment Review, 16(4-6): 223-248.

Reid W V, Chen D, Goldfarb L et al., 2010. Earth system science for global sustainability: Grand challenges. Science, 330: 916-917.

Tang Z, Cao J, Dang J et al., 2014. Interaction between urbanization and eco-environment in arid area of northwest China with constrained water resources: A case of Zhangye city. Arid Land Geography, 37(3): 520-531. (in Chinese)

Vakhlamova T, Rusterholz H P, Kanibolotskaya Y et al., 2014. Changes in plant diversity along an urban-rural gradient in an expanding city in Kazakhstan, Western Siberia. Landscape and Urban Planning, 132: 111-120.

Wang J, Li X, Christakos et al., 2010. Geographical detectors-based health risk assessment and its application in the neural tube defects study of the Heshun region, China. International Journal of Geographical Information Science, 24(1): 107-127.

Wang J, Xu C, 2017. Geodetector: Principle and prospective. Acta Geographica Sinica, 72(1): 116-134. (in Chinese)

Wang X J, Chen Y, 2020. Research on the impact mechanism of urbanization on the efficiency of carbon emissions: An empirical analysis based on panel data from 118 countries in the world. World Regional Studies, 29(3): 503-511. (in Chinese)

Wang X M, Liao J B, Zhang J et al., 2013. A numeric study of regional climate change induced by urban expansion in the Pearl River Delta, China. Journal of Applied Meteorology and Climatology, 53(2): 346-362. 
Wang Z, Liang L, Sun Z et al., 2019. Spatiotemporal differentiation and the factors influencing urbanization and ecological environment synergistic effects within the Beijing-Tianjin-Hebei urban agglomeration. Journal of Environmental Management, 243: 227-239.

Xing J, Yu W, Zhang R et al., 2015. A structural study of the appraisal index system for optimal mining regions in Kazakhstan. Resources Science, 37(5): 1076-1085. (in Chinese)

Xiong C, Yang D, 2015. The relationship between energy consumption and economic growth and the development strategy of a low-carbon economy in Kazakhstan. Journal of Arid Land, 7(5): 706-715.

Yang S T, Yu X Y, Ding J L et al., 2017. A review of water issues research in Central Asia. Acta Geographica Sinica, 72(1): 79-93. (in Chinese)

Yang Y, Liu Y, 2014. Spatio-temporal analysis of urbanization and land and water resources efficiency of oasis cities in Tarim River Basin. Journal of Geographical Sciences, 24(3): 509-525.

Yang Y, Liu Y, Dong W et al., 2011. Spatio-temporal variation analysis of urbanization and land use benefit of oasis urban areas in Xinjiang. Acta Ecologica Sinica, 31(21): 6568-6578. (in Chinese)

Yeerken W Z T, Liu H, Liu W D, 2014. Evaluation of Kazakhstan's urbanization during 1992-2011 and its influencing factors. Progress in Geography, 33(2): 181-193. (in Chinese)

Zhang R, Jiao H, 2015. Coupling and coordination between urbanization and ecological environment in China. Journal of Arid Land Resources and Environment, 29(7): 12-17. (in Chinese)

Zhang S, Shi P, Wang Z et al., 2012. Analysis of coupling between urbanization and water resource and environment of inland river basin in arid region: A case study of Shiyang river basin. Economic Geography, 32(8): 142-148. (in Chinese)

Zhang Y, Yang Q, Min J et al., 2016. An analysis of coupling between the bearing capacity of the ecological environment and the quality of new urbanization in Chongqing. Acta Geographica Sinica, 71(5): 817-828. (in Chinese)

Zhao J J, Liu Y, Zhu Y K et al., 2020. Spatiotemporal differentiation and influencing factors of the coupling and coordinated development of new urbanization and ecological environment in the Yellow River Basin. Resources Science, 42(1): 159-171. (in Chinese)

Zheng F, Liu G Y, Liu Z Y, 2013. Land use change and its coupling relationship with urbanization and industrialization in Xinjiang Uygur Autonomous Region. Research of Soil and Water Conservation, 20(5): $251-256$. (in Chinese) 